\begin{tabular}{|c|c|}
\hline 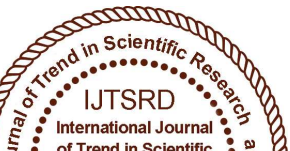 & $\begin{array}{l}\text { International Journal of Trend in Scientific } \\
\text { Research and Development (IJTSRD) }\end{array}$ \\
\hline $\begin{array}{lll} & \\
0\end{array}$ & International Open Access Journal \\
\hline 000 & ISSN No: $2456-6470 \mid$ www.ijtsrd.com | Volume - 2 | Issue -5 \\
\hline
\end{tabular}

\title{
The Conept of Caveat Emptor and Caveat Venditor Still Govern the International Commercial Transation in $21^{\text {th }}$ Centuries
}

\author{
Satish Kumar Singh \\ B. A., L.L.B. (Hons), Indore Institute of Law, \\ Madhya Pradesh, India
}

\begin{abstract}
:
In this research the researcher told about the caveat emptor and caveat venditor and the position of the caveat emptor and caveat venditor in 21 st centuries and how they do the transactions international commercial market, what is the position of the caveat emptor and the caveat venditor in 21 st centuries in international commercial market. And also in his research the researcher told the position of the caveat emptor and the caveat venditor before the 21 st century in international commercial market, and how they do the transaction of the goods and the money at that time. If any defect was arises in the goods at that time then they how to deal their problems of the goods and transactions, and before 21 st century how the supply the goods was done by the seller of the products. In his research the researcher told how the international commercial transactions is different from the other transactions, and also deals before the 21 st centuries how the consumers are protect their rights and what are the changes come in 21 st centuries for the protection of his rights.
\end{abstract}

\section{INTRODUCTION}

The process of the commercial transaction is told in international commercial law. The commercial law is a body of legal rules, conversations treaties and domestic legislation and the international commercial transaction is governed by the international commercial law. A transaction will be said a international commercial transaction when more than one country are involved. In international commercial law some international contracts, these contracts are

sale transaction agreements and this agreements made between parties which are from different countries. ${ }^{1}$

The methods of entering into the international commercial market or foreign market with choice made balancing cost, control, risk and also follow the export policy of the other country and export directly, use the foreign agents for selling and distribution. For the international commercial transaction it is the important for the seller to use the foreign distributor on the sell to the local consumers. ${ }^{2}$ Manufacture the products in his country and export the other countries or set up his business in other countries and acquired the foreign subsidiary and take the licence of the local producer.

Those who wants to setup his business they have another option to enter into a joint venture with a foreign entity or appoint the franchisee in the foreign country.

In the field of international commercial transaction the important role play by the caveat emptor and the caveat venditor. The caveat emptor and the caveat venditor is a legal word. The word caveat emptor means buyer beware and the other word caveat venditor which means seller beware. In international commercial market the UNICTRAL was made a department, the name of the department is this United

\footnotetext{
${ }^{1}$ http://www.mondaq.com/italy/x/40206/Arbitration+Dispute+Re solution/From + Caveat + Emptor + to + Caveat + Venditor + a + Brief + History+of+English+Sale+of+Goods+Law , last visited at 17:12 dated on $03 / 07 / 2018$

${ }^{2}$ http://www.drishtiias.com/upsc-exam-gs-resourcesPRINCIPLE-OF-CAVEAT-EMPTOR-AND-CAVEATVENDITOR, last visited at 17:24 dated on 03/07/2018
} 
Nations convention on contract for the international sale of goods (CISG). And this department is play a important role for the international ale of goods. The convention governs the sale contracts and the obligations of the buyer and the seller and respective remedies of the different countries and the importance of the CISG is its interpretation. ${ }^{3}$ The CISG observed the good faith must be regarded when interpreting the convention. If any dispute arises between buyer and seller the solution is determined according to the general principles of CISG or according to the rules of private international law.

\section{FUNDAMENTAL CONCEPT OF CAVEAT EMPTOR AND CAVEAT VENDITOR IN INTERNATION} TRANSATION:-

The word caveat emptor is a latin word which means buyer beware. This word is mainly used in the real transaction and the buyer assumes the risk that the product may be fail or have some defect. The current system of the international transaction of a market is governed by the caveat emptor and all the services was based on the principle of caveat emptor. For any transaction it is important thing to the buyer or the consumers need to know their rights. The word caveat emptor has been followed for many years by the courts of England. The emptor means buyer and the word caveat is taken from the verb cavere and cavere is the verb of caution. The principle of caveat emptor was the guideline for the courts and the point was that the buyer had a chance to use his knowledge carefully or accept the cost of inattention. ${ }^{4}$ The need of international commercial law is when then the transaction was not fulfilled and the buyer and the seller are also not complete his duty.

The word caveat venditor is a latin word which means seller beware. The principle of caveat venditor forces the seller to take the responsibility of the product and to stop the seller for selling the products of inferior quality. The principle of caveat venditor was a counter to the principle of the caveat emptor and always suggest to the buyer, the seller could also be deceived in any time of market transaction. So for the

\footnotetext{
${ }^{3}$ https://www.britannica.com/topic/commercial-transaction last visited at 17:40 dated on 03/07/2018

${ }^{4}$ Supra Note 1

${ }^{5}$ https://www.lawteacher.net/free-law-essays/commerciallaw/one-of-the-most-powerful-law-essays.php, last visited at 17: 55 date on $04 / 07 / 2018$
}

protection of the buyer the legislature of India make a laws which is known as the name of Consumer Protection Act. If any loss or damage to goods is incurred by a party to the contract carriage then that the person or party can sue the other party directly on the behalf that contract. Insurance against the perils is an important role in international commercial transactions. In the event of loss or damage of the cargo due to the hazardous activities, then the insured party will be able to recover the losses from the insurance. The type of the insurance depends upon the mode of transport agree between the parties to transport the cargo. The insurance obtained must only covered those goods that are being sold stipulated in shipping documents. ${ }^{6}$ In present time the globalized economy is in its peak levels. An so much amounts of the goods are continuously travelling throughout the world in every minute. And the buyers and the sellers are exchange the billions amount of money and goods one another. International commercial law involves in numerous transactions, which lead the problems and disputes between buyer and seller. And when the disputes are arises between buyer and seller then they are provided a lot of work for the lawyers. ${ }^{7}$ So much problems are arises when then the international commercial transactions dispute are come under the two countries and the laws are different of both countries. Therefore the legal practices and interpretation of obligations vary drastically from state to state.

\section{LEGAL FRAMEWORK FOR THE INTERNATIONAL COMMERCIAL TRANSATION AND THE CAVEAT AND THE CAVEAT VENDITOR IN $21^{\text {ST }}$ CENTIURIES:-}

In $21^{\text {st }}$ centuries the caveat emptor and caveat venditor are the most important part for the international commercial transaction. If anyone is not follow the perfect rule of the transaction the so much disputes are arises between them. Then they are go to the court for the resolution of their dispute and they are hire the lawyers for the protection of his rights. Then they are provided the a lot of work to the lawyers. And many time they were faced the s much problems of laws because some time the laws are different of the different countries, then liabilities incurred in pre - contractual conversations. It is the

\footnotetext{
${ }^{6}$ https://www.lawteacher.net/free-law-essays/internationallaw/importance-incoterms-international-sales-contractsinternational-law-essay.php, last visited at 18:03 dated on 04/07/2018

${ }^{7}$ IBID
} 
common instance that parties come from different jurisdictions, so each of them may be compliant under its own laws, however it is to be decided what happens in the event that these positions clash. ${ }^{8}$

In every time the parties are inter into the international commercial transaction and usually agree in the contract and these parties are not decided which law will be applicable if any dispute will arise. So for the resolution EU harmonised rules as to conflict of law rules apply, but this is not the case in the other jurisdictions, which apply different approaches. Arbitration is the key word for the resolution of international commercial transaction in India. The rule of arbitration most of the countries are adopted after the UN commission on international Trade law, model laws, arbitration law and practice enjoy a certain level of uniformity across nations. UN commission has made the arbitration an attractive mode of dispute resolution for foreign investors in many countries.

In some countries oral agreements are also applicable, like that UK and some countries this type of agreement will have no value. For the resolution of international commercial transactions the international commercial laws are applicable and the EU has enacted uniformed rules as to the determination of the competent court. Outside the EU however, the procedure is not clear and each state applied its own conflict of law rules. The most common reason for the commercial dispute between buyer and the seller is a claim from one party due to nonconforming goods and it is also commercial issue for the transactions. ${ }^{9}$

In India commercial litigation is a long time consuming process so arbitration has preferred mode of dispute resolution in India. India has a very exhaustive law on arbitration. The first law of arbitration was came in 1899 in the form of Arbitration act 1899.

India is also became a signatory to the convention of recognition and enforcement of foreign arbitral awards at New York, this convention is also known as

\footnotetext{
${ }^{8} \mathrm{http}: / /$ linkilaw.com/blog/most-common-internationalcommercial-law-issues-explained, last visited at 18:17 dated on 04/07/2018

${ }^{9}$ https://www.americanbar.org/publications/international_law_ne ws/2013/summer/arbitration_in_international_commercial_trans actions_indian_courts_to_the_rescue.html, last visited at 18:28 dated on $04 / 07 / 2018$
}

the name of New York convention. Which provided a simple and effective method of recognition and enforcement of foreign awards. The India was adopted the Arbitration and conciliation Act in 1996. This law expressly deal with the domestic and as well as international commercial dispute. The Arbitration Act stakes into account the 1985 UNCITRAL model laws.

In the case of Bharat aluminum Co. vs. Kaiser aluminum technical services the supreme court given the judgement if arbitration is conducted outside India, then the parties have option they could approach the courts in India for a judicial process and they could stall the entire arbitration process. ${ }^{10}$ The judgement of this case is binding the nature of arbitration proceeding conducted outside India in international commercial contracts involving India related matters. After some time the internationally, arbitration laws is developed in different countries for the fulfillment of needs of different countries. In India for the resolution of international commercial transactions the arbitration act is divided into four parts, and all the parts are doing the different types of work.

First part deals with the regulations arbitration proceeding held in India and this act empowered the parties to arbitration to provides the interim relief from the Indian courts before the commencement of arbitration or during its pendency, and the second part provides for the enforcement of foreign awards, ${ }^{11}$ third part deal with the conciliation and the forth and last part deals the supplementary provisions.

\section{EVALUTION AND DEVELOPMENT OF THE CAVEAT EMPTOR AND CAVEAT VENDITORIN $21^{\text {ST }}$ CENTURIES:-}

The word caveat emptor and the caveat venditor is mostly use in $21^{\text {st }}$ centuries after coming the consumer protection act. This act is protecting the rights of the consumers and always told his duty of buyer and seller. This act also protected the exploitation and abuse by any manufacturer or supplier of goods and services. After some time this idea of consumer protection can be found to every kind of social order and judicial mechanism that is primitive or modern. This protection act is not only follow for the

\footnotetext{
${ }^{10}$ IBID

${ }^{11} \mathrm{https}$ //Www.stimmel-law.com/en/articles/internationalcommercial-transactions-standard-terms-and-conditions, last visited at 13:12 dated on $05 / 07 / 2018$
} 
customary norms of buying and seeking services but also from many religious ordainment and commands of kings. ${ }^{12}$ At that time the protection of the consumers was continuous with different process, and the major development of the protection of the product safety standards are occurred in U. K. and U.S.

In England at the time of $13^{\text {th }}$ and the $14^{\text {th }}$ centuries the consumer protection was limited and only the control of the prices of important commodities and also the protection of the short supplies. The quality and the quantity of the products like that milk, butter, meat, fuel and bread etc. are regulated by the crown of England through judicial institution. The position of the consumer was not satisfactory and they were deceived and oppressed. Before the commencement of the modern consumer movement, the consumers had to depend upon the ordinary remedies for defective products under: law which is relating to implied condition and warranties of the goods or products. Under the common law, we are studies the evolution of product safety and standard of the goods. $^{13}$

The law of contracts and the law of torts are come under the common law. Every person has right to do a contract and they are free to do the contract. The contract is the basis of commercial dealings. The law recognized the rights of the parties, if once an agreement is made then the parties are bound to complete the contract if any party is breach the contract, then another party have option to go to the court and the court shall be provided the appropriate remedies for the breach of contract. ${ }^{14}$

In $18^{\text {th }}$ centuries under common law has great emphasis of political theory upon the concept of human liability and individualistic theory, which is governed by the enlightened people for self interest. In $18^{\text {th }}$ centuries which parties were doing the contract, they were making the laws for themselves. They did not infringe the legal prohibition, they could make the rules what they liked in the respect of the subject matter of their agreement and the law would give the effect of their decision and they are follow the rules. The individualistic theory introduced the

\footnotetext{
${ }^{12} \mathrm{http}: / /$ www.drishtiias.com/upsc-exam-gs-resourcesPRINCIPLE-OF-CAVEAT-EMPTOR-AND-CAVEATVENDITOR , last visited at 13:19, dated on 05/09/2018 ${ }^{13}$ IBID

${ }^{14}$ Supra Note 4
}

monopolistic capitalist sector and led to the concentration of wealth in few hands.

There are the several cases which related to the consumer and the manufacturer of the goods, maximum cases are related to the qualities of the goods and defect in products. In this condition between the consumer and the manufacturer rises a collateral contract. In $19^{\text {th }}$ centuries the word buyer summed up by the maxim caveat emptor which means let the buyer beware. This maxim summarized the rule of purchase for the purchaser and decided what the best is for him. The buyer use his skill and judgement, when he makes the purchase.

\section{JUDICIAL TRANDS OF THE COMMERICAL TRANSATION AND RELATED CASE LAW RELEATED OF THE CAVEAT EMPITOR AND CAVEAT VENDITOR:-}

In maximum cases the manufacturer held liable where the products was not good like as the description and the buyer was the Injured after using the products, because the collateral contract between the buyer and the seller. This information is leading case of CARBOLIC SMOKE BALL CASE - The defendant is the in the instant case was the manufacture of the medicine called smoke ball for curing disease "influenza". the defendant in their advertisement assured that the medicine would cure influenza completely if it is used for $15^{\text {th }}$ days as per the given directions.

The defendant also announced a reward of 1000 pounds to anyone who suffers from influenza when after using the medicine for $15^{\text {th }}$ days as per the given direction and smoke ball Co. Deposited 1000 pounds in the bank to show their sincerity in this regard. Mrs. Carlill is response this advertisement purchase this medicine (Smoke Ball) and used it as per the printed directions but influenza attacked again, then she filed a suit against the manufacturer company for the reward of 1000 pounds. ${ }^{15}$

The court was held that the defendant was liable on the ground that the defendant's advertisement containing a reward was for general public and it was open for all and be accepted by anyone purchase the medicine and used it so the purchaser of the medicine is entitle to get the reward. ${ }^{16}$

\footnotetext{
${ }^{15}$ https://www.lawteacher.net/cases/carlill-v-carbolic-smoke-ballco.php, last visited at13:39 dated on 06/07/2018 ${ }^{16}$ IBID
} 
Some cases which are related to the caveat emptor and caveat venditor leading in this page.

In Akhil Bhartiya Grahak Phanchayat V. Meghna Metals and others: - The complainant purchase prestige pressure cooker from the opposite party inspite of special gasket relief system for safety, the cooker burst which resulted damage to right hand of the complainant wife. The opposite party was held liable to pay compensation Rs. 10000 +reimp medical bills although wife was the user of goods and not the buyer but she used the goods of the approvals of the buyer. ${ }^{17}$

Smt. Puspa Meena V. Shah Enterprise: - This case is from Rajasthan limited - In this case the appellant purchase a jeep for the commercial purpose. That is for transportation of passengers for him when jeep started giving troubled sued the respondent company under consumer protection act. This case was not actionable on the ground that the appellant could not be treated as a consumer within the meaning of the act. $^{18}$

Lakshmi Engineering works V. P.S.G. Industrial Institute: - The appellant Lakshmi engineering company paid the amount to the respondents, P.S.G industrial Institute for the supply the machinery in May 1990. Again several reminders the machine was supply after $6^{\text {th }}$ month in defective condition, owing to inordinate delay in a defects in the machine, the appellant sustain have loss due to non - production and other expenses. The appellant filed a complaint before the state commission for compensation for a Rs. 400000. Party company allowing, the complaint the state commission directed the respondent manufactures to pay Rs. 2.48000 within 30 days. On appeal the national commission held that the complainant is not to be regarded as a consumer within the meaning of award in set a side of a award is a state commission. After the decision of the state commission the aggrieved party further appeal before the Supreme Court. ${ }^{19}$

\footnotetext{
${ }^{17} \mathrm{http}: / /$ www.lawyerservices.in/Akhil-Bhartiya-Grahak-

Panchayat-Versus-Ms-Meghna-Metals-and-Another-1993-03-11, last visited at 06/07/2018, dated on 14:16

${ }^{18} \mathrm{http}$ ://www.lawyersclubindia.com/forum/Who-is-a-Consumer-231.asp, last visited on 07/07/2018, dated on 14:29

${ }^{19}$ https://www.business-

standard.com/article/specials/commercial-purpose-defined-

196090401136 1.html, last visited on $07 / 07 / 2018$, dated on 14:40
}

\section{CONCLUSION:-}

In India present time the protection of the consumers the legislature of India passed the act the name of the act is Consumer protection act. This act was passed by the parliament of India 1986. The purpose of this act is to protect the rights of consumers and introduce the quality and the purity of the goods and also the purpose of this act is that to protect the consumers against exploitation and abuse by the any manufacturer or the supplier of the goods.

The idea of the consumer protection can be found by the judicial mechanism and social order. The idea of the consumer protection ancient in time is same like that, which means at that time the for the protection of consumer the rulers are used the social order and the judicial mechanism. In ancient time the buyer and seller are protected their rights through religious ordainment's and commands of the king. The major development were done by the England, United state of America for the protection of consumers, buyer and seller.

At the time of $13^{\text {th }}$ and $14^{\text {th }}$ centuries in England, the protection of the consumer was limited and the government was only protect the rights of the consumer to control the price of some important goods and shortage of supply. At that time some important goods like fuel, butter, meat, bread etc. were regulated by the crown of England through judicial institution.

Before the commencement of the modern consumer movement, the consumers had to depend the ordinary remedies for defective products. If any seller was deceive to the consumer then that the seller was held the liable and pay the penalties to the consumer for his act.

International commercial transaction is a different then other transactions because this transaction is done by the two different countries and the laws are different for every countries if any dispute is arises between the transaction then the UNO was made a law for the resolution of the dispute of the international commercial transactions. The name of the law is international commercial law. 